\title{
Foreign Language Anxiety in Saudi Classroom: A Case Study of Saudi Tertiary Female Students in Prince Sattam University
}

\author{
Asjad Ahmed Saeed Balla ${ }^{1}$ \\ ${ }^{1}$ Gedarif University /Sudan; Prince Sattam University, KSA \\ Correspondence: Asjad Ahmed Saeed Balla, Gedarif University, Sudan; Prince Sattam University, KSA. E-mail: \\ gamar6@hotmail.com
}

Received: February 22, 2017

Accepted: April 2, 2017 Online Published: April 6, 2017

doi: 10.5539/elt.v10n5p28

URL: http://doi.org/10.5539/elt.v10n5p28

\begin{abstract}
This paper investigates the level of anxiety due to learning English as a foreign language. It tries to answer these questions: 1-Is anxiety a factor in hindering English proficiency? 2-Does anxiety lead to fear of communication? 3- Which type of anxiety is high among tertiary level female Saudi students? The Foreign Language Anxiety Classroom Scale (FLACS) used as an instrument. The data was collected and statistically analysed through SPSS. This paper revealed that anxiety was one of the major factors that impeded English proficiency. Besides, anxiety also caused fear of communication among the students. Furthermore, it was found that the learners had got a high level of communication apprehension that hindered their contact with their teachers and others. This was followed by test anxiety in which the students expected to fail their test. Students showed great fear of test as they feared to be negatively assessed by teachers, this fact had created great anxiety that influenced their attitudes and behaviour as well.
\end{abstract}

Keywords: anxiety, communication apprehention, fear, English proficiency

\section{Introduction}

Students feel anxious when they are not sure of their ability to practice the foreign language and this may be due to some factors such as age, fear, self-confidence, self-esteem etc.

This anxiety influences the students positively or negatively in their learning process which consequently affects their performance and achievement. Gardner's (1991) emphasize this apart from its effect in positive or negative sides, they declare that "anxious individuals think about their own reaction to a task in addition to the demands of the task itself."(p. 297).

Their definition stated that individuals think first about how they are going to do the job more than what they need to achieve it. This thinking raises their anxiety if they are going to do it well or not, similar to the situation of the second foreign language learners who are thinking in the first place of the negatives rather the positives. MacIntyre and Gardner (cited in Gkonou, 2012) explain that if anxious students focus on positive experience in second language rather than negative ones, the debilitating effect of language anxiety could be reduced.

Researchers of language anxiety such as Ellis (2008); Horwitz and Young (1991), Macintyre (1991), considered that language anxiety appears in specific situation. This resulted on that students who experience language anxiety are not necessary having poor study habits and difficulty on other class rather than foreign language learning. Students try to communicate in another language which is not like theirs (linguistically, socially, or culturally) and their feeling that they are under spot (evaluation) and consequently their anxiety rises. Interpretatively, Horwitz et al. (1986) writes, "as individual's communication attempts will be evaluated according to uncertain or even unknown linguistic or socio-cultural standards, second language communication entails risk-taking and in necessarily problematic" (p. 128). In addition Dornyei (2001 cited in Gkonou, 2012) describes the language classes as "inherently face threating environment."

According to all above, what is expected from language students put a burden on them. In addition to that the challenge for good performance and achievement is another good reason to add more burdens. Evaluation and other factors in the learning environment may help create the foreign language classroom anxiety (FLCA).

Globalization and Saudi marketplace have a great demand for English language skills. For this end Saudi educational system has been changed. Beside the private colleges and universities turned to teach using English 
not only for foreign language classes but also in other classes. Before that, English used to be taught as a subject. Saudi government tries recently to improve teaching and learning English as a foreign language. The problem is that the majority of Saudi EFL learners suffers of a very low proficiency in English. Students appear reluctant, unwilling to participate or discuss and rely totally on their teachers. Reception, memorization and reproduction are the strategies of learning in Saudi context. All these factors create a high level of anxiety and give negative impact of Saudi EFL learners (Al-Sibai, 2005)

Saudi Arabia also has a conservative, religious and strong tradition culture. Accordingly, a challenge rises and resists to new changes (such as studying English). Consequently, anxiety manifests in studying EFL in Saudi context (Al-Saraj, 2014).

\subsection{Study Questions}

This research paper tries to answer the following questions:

1)- Is anxiety a factor in hindering English proficiency?

2)- Does anxiety lead to fear communication?

3)- Which type of anxiety is high among tertiary level female Saudi students?

\section{Literature Review}

Spielberger (1983 cited in Horwitz, Horwitz, \& Cope, 1991) states anxiety as "subjective feeling of tension, apprehension, nervousness, and worry associated with an aroused of automatic nervous system" (p. 27). Meanwhile another definition recorded by Abu-Rabai (2004), which is "fear, panic and worry (p. 71) Maclntyre (1998) express LA (LA stands for language anxiety) as "the worry and negative emotional reaction aroused when learning or using a second language (p. 27). While Abu-Rabia (2004) defines the foreign language learner characterized as having anxiety is usually "worried, physically insecure and unable to engage in situational learning" (p. 712). Chan and Wu (2004) count what the mostly sources that cause students' foreign language anxiety". In addition to task difficulty, factors such as teachers' attitude and evaluation, teacher-students interactions in class, parents' expectations, classmates' attitudes, students' own achievement are potential sources of students' foreign language anxiety" (p. 290). Meanwhile, Young (1991) (cited in Awan, Azhar, Anwar, \& Naz, 2010) spoke about/pointed out six points as sources of second language anxiety: 1. Personal and interpersonal oissues. 2. Instructor learner interactions. 3. Classroom procedures. 4. Language testing. 5. Instructor beliefs about language learning and 6.learners' beliefs about language learning.In addition, other factors associated with anxiety such as age, motivation, emotional intelligence and learning difficulties (Awan, Azhar, Anwar, \& Naz, 2010).

The base of all these definition was the claim raised by Horwitz (cited in Horwitz \& Cope, 1986) as he declares that, "FLA is a phenomenon related to but distinguishable from other specific anxiety as the first who made it stands as a unique type of anxiety specific to foreign language learning" (p. 129).

According to Horwitz and Cope (1986) there are three components in foreign language anxiety: firstly, communication apprehension, secondly, test anxiety and thirdly, is fear of negative evaluation on which they built their Foreign Language Classroom Anxiety Scale (FLCAS) (cited in Salehi, Marefat, 2014)

Spielberger (1983) (cited in Tovilovic, Novovic, Mihic, \& Jovanovic, 2009) recorded that state anxiety is an unpleasant emotional response while coping with threatening or dangerous situation. Mathews, Deary and Whileman (2003) defines state anxiety as "any reliably measured characteristic, but typically state variables refer to conscious, verbally reportable qualities such as moods" (p. 77). For trait anxiety Spielberger (1999 in T, N, M. 2009) pointed out trait anxiety as a general disposition to experience transient states of anxiety, suggesting that these two constructs are inter-related.

There are three types of anxiety as follows:

1). Trait anxiety which correlates with personality characteristic.

2). State anxiety worries known at a certain moment in time.

3). Situational anxiety which takes place in a well-defined situation (Maclntye \& Gardener, 1991a)

The class room anxiety especially that connected with studying another language is known as a Foreign Language Class room Anxiety (FLCA). In 1980 Clement has recorded that foreign language anxiety is a complex construct that deals with the learners' psychology in terms of their feeling, self-esteem and self-confidence. This is confirmed by Horwitz et al. (1986) as "a distinct complex of self-perceptions, beliefs, feelings and behaviours related to classroom language learning arising from the uniqueness of the language 
learning process" (p. 128). Inthe same direction Young (1992) defined it as a complicated psychological phenomenon peculiar to language learning. More specifically Maclntyre and Gardener (1994b) stated FLA as the feeling of tension and apprehension specifically associated with second or foreign language context, includingspeaking, listening and learning. Maclntyre emphasizes this as he said 'the worry and negative emotional reaction arousal when learning or using second or foreign language. Agreeing with Maclntyre, Zhang (2001) (cited in Trang, 2012) who saw anxiety as the psychological tension that the learner goes through performing a learning task.

Horwitz et al (1986) defines the first components of language anxiety, communication apprehension as "a type of shyness characterized by fear of or anxiety about communicating with people" (p. 127).

The second component is fear of negative evaluation is also defined by Horwitz et al. (1986) (cited in Alrabai 2014) as "apprehension about others' evaluation, avoidance of evaluative situations, and the expectation that others will evaluate negatively". The third components is test anxiety which defines by Maclntyre and Gardener (1898) as "an apprehension over academic evaluation" (p. 42).

\section{Methodology}

In (1986), Horwitz introduced Foreign Language Classroom Anxiety Scale (FLCAS). It is evolved by him .It is used to speculate learners' anxiety. It set to measure and assess the three components that stated by Horwitz et al 1986.These are communication apprehension, fear of negative evaluation and test anxiety. FLACS consists of 33 items in five points Likert scale of agreement, in positively and negatively wording (24-9) . Theory of foreign anxiety by Horwitz et al's have been acknowledged for its uniqueness and accepted widely for its reliability (Tran, 2012).

In a factor analysis of FLACS conducted by Aida (1994) before using it in Japanese context. She reported four factors: speech anxiety; fear of failing; comfort and negative attitudes.

In (2000-2001) a study carried out by Perez-Paredes and Martinez-Sanches in which they used Spanish version of FLACS. Many more studies applied FLACS on different contexts.

The researcher applied Cronbach's Alpha Coefficient for all the scales questions which shows high reliability as in the table below:

\section{Reliability Statistics}

\begin{tabular}{lll}
\hline & Cronbach's Alpha & N of Items \\
\hline All questionssurvey & .715 & 33 \\
\hline
\end{tabular}

For the structure validity table No.1 below shows that the correlation coefficient for all the variables with the overall average is statistically significant at the level of significance $(\alpha=0.05)$, and $(\alpha=0.01)$, which confirms that the questionnaire attains high degree of structure validity.

Table 1. Correlation coefficient spearman'

\begin{tabular}{|c|c|c|}
\hline & \multicolumn{2}{|c|}{ Total Mean } \\
\hline & \multicolumn{2}{|c|}{$\begin{array}{l}\text { CorrelationSig. } \\
\text { Coefficient(2-tailed) }\end{array}$} \\
\hline I never feel quite sure of myself when I am speaking in my foreign language class & .188 & .205 \\
\hline I don't worry about making mistakes in language class & .020 & .893 \\
\hline I tremble when I know that I'm going to be called on in language class & $.466^{* *}$ & .001 \\
\hline It frightens me when I don't understand what the teacher is saying in the foreign languag & $.584^{* *}$ & .000 \\
\hline It wouldn't bother me at all to take more foreign language classes & .166 & .266 \\
\hline $\begin{array}{l}\text { During language class, I find myself thinking about things that have nothing to do with } \\
\text { course. }\end{array}$ & e. 170 & .253 \\
\hline I keep thinking that the other students are better at languages than I am & $.348^{*}$ & .017 \\
\hline I am usually at ease during tests in my language class & .164 & .270 \\
\hline
\end{tabular}


I start to panic when I have to speak without preparation in language class

I worry about the consequences of failing my foreign language class

I don't understand why some people get so upset over foreign language classes

In language class, I can get so nervous I forget things I know

It embarrasses me to volunteer answers in my language class

I would not be nervous speaking the foreign language with native speakers

I get upset when I don't understand what the teacher is correcting

Even if I am well prepared for language class, I feel anxious about it

I often feel like not going to my language class

I feel confident when I speak in foreign language class

I am afraid that my language teacher is ready to correct every mistake I make

I can feel my heart pounding when I'm going to be called on in language class

The more I study for a language test, the more con- fused I get

I don't feel pressure to prepare very well for language class

I always feel that the other students speak the foreign language better than I do

I feel very self-conscious about speaking the foreign language in front of other students

Language class moves so quickly I worry about getting left behind

I feel more tense and nervous in my language class than in my other classes

I get nervous and confused when I am speaking in my language class

When I'm on my way to language class, I feel very sure and relaxed

I get nervous when I don't understand every word the language teacher says

I feel overwhelmed by the number of rules you have to learn to speak a foreign language

I am afraid that the other students will laugh at me when I speak the foreign language

I would probably feel comfortable around native speakers of the foreign language

I get nervous when the language teacher asks questions which I haven't prepared in advance

$\begin{array}{ll}.481^{* *} & .001 \\ .321^{*} & .028 \\ .145 & .330 \\ .328^{*} & .024 \\ .559^{* *} & .000 \\ .017 & .908 \\ .453^{* *} & .001 \\ .428^{* *} & .003 \\ .377^{* *} & .009 \\ .131 & .381 \\ .457^{* *} & .001 \\ .294^{*} & .045 \\ .338^{*} & .020 \\ -.045 & .766 \\ .413^{* *} & .004 \\ .232 & .117 \\ .406^{* *} & .005 \\ .399^{* *} & .006 \\ .401^{* *} & .005 \\ .129 & .387 \\ .340^{*} & .019 \\ .289^{*} & .049 \\ .513^{* *} & .000 \\ -.006 & .970 \\ .407^{* *} & .005\end{array}$

*. Correlation is significant at the 0.05 level (2-tailed).

**. Correlation is significant at the 0.01 level (2-tailed).

Horwitz (1986) revealed the items of FLACS connected to the each components of FLACS as follows: (items 1, $4,9,14,15,18,24,27,29,30$, and 32) resembles communication apprehension,

(items 3, 5, 6, 8, 10, 11, 12, 16, 17, 20, 21, 22, 25, 26, and 28) represent test anxiety,(items 2, 7, 13, 19, 23, 31 and 33) symbolize fear of negative evaluation.

FLACS is reliable, its reliability demonstrated by Horwitz (1980) when he announced a Cronbach's Alpha coefficient for the first test which was $93(\mathrm{~N}=108), 83(\mathrm{~N}=78)$ for the second test that carried out after eight weeks. Many researchers such as Aida (1994) Cheng, Horwitz and Schallert (1999), Elkhafaifi (2005) and Zhang. (2010) (Alrabai, 2014) wrote to prove FLACS reliability.

\subsection{Participants}

The participants are a group of students of the third year Department of English, College of Science and Humanity Studies, Prince Sattam ibn Abdulaziz University in Aflaj. These young learners face of a lot of problems that cause low achievement. This is an attempt to address some of these problems in this paper.

The subjects were studying a course entitled (Discourse Analysis) in where the researcher noticed their low proficiency in English and high tension while they were presenting or participating in pair or in group.

\subsection{Data analysis, Discussion and Results}

Data is analysed using SPSS. Correlation coefficient, Frequencies, Mean, Standard Deviation and One Sample 
Test ( $\mathrm{T}$-Test) were applied.

Table2 below shows the Mean and Standard Deviation that revealed 3.7 with high mean which indicates that all the participant agreed on these two items (items No. 9 and No. 33). Both items show communication apprehension.

Table 2. The mean and standard deviation

Mean and Std. Deviation

\begin{tabular}{|c|c|c|}
\hline & Mean & $\begin{array}{l}\text { Std. } \\
\text { Deviation }\end{array}$ \\
\hline I never feel quite sure of myself when I am speaking in my foreign language class & 3.30 & .858 \\
\hline I don't worry about making mistakes in language class & 2.85 & 1.000 \\
\hline I tremble when I know that I'm going to be called on in language class & 3.28 & .971 \\
\hline It frightens me when I don't understand what the teacher is saying in the foreign language & 3.26 & 1.010 \\
\hline It wouldn't bother me at all to take more foreign language classes & 3.09 & 1.120 \\
\hline During language class, I find myself thinking about things that have nothing to do with the course. & 3.02 & 1.032 \\
\hline I keep thinking that the other students are better at languages than I am & 3.17 & .963 \\
\hline I am usually at ease during tests in my language class & 3.17 & .940 \\
\hline I start to panic when I have to speak without preparation in language class & 3.70 & .858 \\
\hline I worry about the consequences of failing my foreign language class & 3.30 & 1.250 \\
\hline I don't understand why some people get so upset over foreign language classes & 3.36 & 1.092 \\
\hline In language class, I can get so nervous I forget things I know & 3.55 & .974 \\
\hline It embarrasses me to volunteer answers in my language class & 3.45 & 1.119 \\
\hline I would not be nervous speaking the foreign language with native speakers & 3.34 & .984 \\
\hline I get upset when I don't understand what the teacher is correcting & 3.06 & 1.030 \\
\hline Even if I am well prepared for language class, I feel anxious about it & 3.53 & .856 \\
\hline I often feel like not going to my language class & 2.70 & .998 \\
\hline I feel confident when I speak in foreign language class & 3.40 & .993 \\
\hline I am afraid that my language teacher is ready to correct every mistake I make & 2.98 & 1.151 \\
\hline I can feel my heart pounding when I'm going to be called on in language class & 3.30 & .976 \\
\hline The more I study for a language test, the more con- fused I get & 3.47 & 1.039 \\
\hline I don't feel pressure to prepare very well for language class & 2.77 & 1.068 \\
\hline I always feel that the other students speak the foreign language better than I do & 3.02 & 1.011 \\
\hline I feel very self-conscious about speaking the foreign language in front of other students & 3.30 & .778 \\
\hline Language class moves so quickly I worry about getting left behind & 3.45 & 1.138 \\
\hline I feel more tense and nervous in my language class than in my other classes & 2.87 & 1.115 \\
\hline I get nervous and confused when I am speaking in my language class & 3.30 & .858 \\
\hline When I'm on my way to language class, I feel very sure and relaxed & 3.53 & .905 \\
\hline I get nervous when I don't understand every word the language teacher says & 3.21 & 1.082 \\
\hline I feel overwhelmed by the number of rules you have to learn to speak a foreign language & 3.45 & .974 \\
\hline I am afraid that the other students will laugh at me when I speak the foreign language & 2.79 & 1.301 \\
\hline I would probably feel comfortable around native speakers of the foreign language & 3.38 & .898 \\
\hline I get nervous when the language teacher asks questions which I haven't prepared in advance & 3.70 & 1.061 \\
\hline Total Mean & \multicolumn{2}{|c|}{3.2437 .31141} \\
\hline
\end{tabular}


T-Test revealed that the participants reacted negatively to items ( 1 never feel quite sure of myself when I am speaking in my foreign language class). Item (12. In language class, I can get so nervous I forget things I know). Both indicates high level of communication apprehension. Conversely, they reacted positively towards item (11, I don't understand why some people get so upset over foreign language classes). This shows less anxiety to English classes. Unlikely, the respondents show high level of again communication apprehension in item (13. It embarrasses me to volunteer answers in my language class). Paradoxically, they showed less level of communication apprehension when they speak to native speakers as appears in item 14 which reads (14.I would not be nervous speaking foreign language with native speakers).

On the other hand, they showed high level of anxiety as in items 16 and 17 (16. Even if I am well prepared for language class, I feel anxious about it), (17. I often feel like not going to my language class). The participant showed expressed a high level of fear of negative evaluation in answering item20. (20. I can feel my heart pounding when I am going to be called on in language class).while their test anxiety became clear when they responded to item 21. (21. The more I study for a language test, the more confused I get).

The respondents seems to be in a very high level of communication anxiety as reacting to item 24 , where it reads (24. I feel very self-conscious about speaking the foreign language in front of other students). Moreover their responses towards item 25 (25. Language class move so quickly I worry about getting left behind) showed a high level of fearing negative evaluation. More high level of communication apprehension appeared in the respondents' answers to item 27. (27. I getnervous and confused when I am speaking in my language class.

Contrastingly with their responses towards item 27, the participants showed a very low level of English classroom anxiety when they reacted to item 28 (28. When I'm on my way to language class, I feel very sure and relaxed).

In a completely different response the respondents made towards item 30 which showed a high level of classroom anxiety, (30. I feel overwhelmed by the number of rules you have to learn to speak a foreign language.) In a low level of communication apprehension the participants responded to item 32 that reads (32. I would probably feel comfortable around native speaker of foreign language). While their responding to item 33 showed a high level of fearing of negative evaluation. (33. I get nervous when the language teacher asks questions which I haven't prepared in advance.)

Table 3 below shows One-Sample Test (T-test)

There is a statistically significant relationship at the level of significance $(\alpha=0.05)$ between the study variables and the level of anxiety. The average degree of anxiety considered $(M=3)$

The Null hypothesis and the Alternative hypothesis were formulated as follows:

Null hypothesis is $H_{0}: M=3$

Alternative hypothesis is $H_{l}: M \neq 3$

Table 3. Sample Test (T-test)

\begin{tabular}{|c|c|c|c|c|c|}
\hline \multicolumn{6}{|l|}{ One-Sample Test } \\
\hline & \multicolumn{5}{|c|}{ Test Value $=3$} \\
\hline & & & & Mean & \\
\hline & $\mathrm{t}$ & df & Sig. (2-tailed) & Difference & \\
\hline I never feel quite sure of myself when I am speaking in my foreign language class & 2.381 & 46 & .021 & .298 & Reject $H_{0}$ \\
\hline I don't worry about making mistakes in language class & -1.022 & 46 & .312 & -.149 & Accept $H_{0}$ \\
\hline I tremble when I know that I'm going to be called on in language class & 1.952 & 46 & .057 & .277 & Accept $H_{0}$ \\
\hline It frightens me when I don't understand what the teacher is saying in the foreign language & 1.733 & 46 & .090 & .255 & Accept $H_{0}$ \\
\hline It wouldn't bother me at all to take more foreign language classes & .521 & 46 & .605 & .085 & Accept $H_{0}$ \\
\hline During language class, I find myself thinking about things that have nothing to do with the course. & .141 & 46 & .888 & .021 & Accept $H_{0}$ \\
\hline I keep thinking that the other students are better at languages than I am & 1.212 & 46 & .232 & .170 & Accept $H_{0}$ \\
\hline I am usually at ease during tests in my language class & 1.242 & 46 & .221 & .170 & Accept $H_{0}$ \\
\hline
\end{tabular}


I start to panic when I have to speak without preparation in language class

I worry about the consequences of failing my foreign language class

I don't understand why some people get so upset over foreign language classes

In language class, I can get so nervous I forget things I know

It embarrasses me to volunteer answers in my language class

I would not be nervous speaking the foreign language with native speakers

I get upset when I don't understand what the teacher is correcting

Even if I am well prepared for language class, I feel anxious about it

I often feel like not going to my language class

I feel confident when I speak in foreign language class

I am afraid that my language teacher is ready to correct every mistake I make

I can feel my heart pounding when I'm going to be called on in language class

The more I study for a language test, the more con- fused I get

I don't feel pressure to prepare very well for language class

I always feel that the other students speak the foreign language better than I do

I feel very self-conscious about speaking the foreign language in front of other students

Language class moves so quickly I worry about getting left behind

I feel more tense and nervous in my language class than in my other classes

I get nervous and confused when I am speaking in my language class

When I'm on my way to language class, I feel very sure and relaxed

I get nervous when I don't understand every word the language teacher says

I feel overwhelmed by the number of rules you have to learn to speak a foreign language

I am afraid that the other students will laugh at me when I speak the foreign language

I would probably feel comfortable around native speakers of the foreign language

I get nervous when the language teacher asks questions which I haven't prepared in advance

Total Mean

\begin{tabular}{lllll}
5.613 & 46 & .000 & .702 & Reject $H_{0}$ \\
1.634 & 46 & .109 & .298 & Accept $H_{0}$ \\
2.271 & 46 & .028 & .362 & Reject $H_{0}$ \\
3.895 & 46 & .000 & .553 & Reject $H_{0}$ \\
2.737 & 46 & .009 & .447 & Reject $H_{0}$ \\
2.371 & 46 & .022 & .340 & Reject $H_{0}$ \\
.425 & 46 & .673 & .064 & Accept $H_{0}$ \\
4.260 & 46 & .000 & .532 & Reject $H_{0}$ \\
-2.046 & 46 & .047 & -.298 & Reject $H_{0}$ \\
2.792 & 46 & .008 & .404 & Reject $H_{0}$ \\
-.127 & 46 & .900 & -.021 & Accept $H_{0}$ \\
2.092 & 46 & .042 & .298 & Reject $H_{0}$ \\
3.087 & 46 & .003 & .468 & Reject $H_{0}$ \\
-1.503 & 46 & .140 & -.234 & Accept $H_{0}$ \\
.144 & 46 & .886 & .021 & Accept $H_{0}$ \\
2.625 & 46 & .012 & .298 & Reject $H_{0}$ \\
2.691 & 46 & .010 & .447 & Reject $H_{0}$ \\
-.785 & 46 & .437 & -.128 & Accept $H_{0}$ \\
2.381 & 46 & .021 & .298 & Reject $H_{0}$ \\
4.028 & 46 & .000 & .532 & Reject $H_{0}$ \\
1.348 & 46 & .184 & .213 & Accept $H_{0}$ \\
3.146 & 46 & .003 & .447 & Reject $H_{0}$ \\
-1.121 & 46 & .268 & -.213 & Accept $H_{0}$ \\
2.923 & 46 & .005 & .383 & Reject $H_{0}$ \\
4.535 & 46 & .000 & .702 & Reject $H_{0}$ \\
5.365 & 46 & .000 & .24371 & Reject $H_{0}$ \\
\hline & & & &
\end{tabular}

\section{Conclusion}

To conclude, three questions of the study have been answered. For the first question, the study proved that anxiety was an influential factor in hindering English proficiency. It also confirmed that anxiety affected students' communication negatively. The results showed students' high anxiety level due to communication apprehension followed by test anxiety and fear of negative evaluation. Communication is the ultimate goal that language learners are supposed to be seeking. Good communication skills are often a key for brighter career. Anxiety can influence the students' communication skills; while fear of test would mean students fear of failure. It may be attributed to the fear of failing before his/her beers, family and consequently the society with special focus on the nature of society in this area, which is (very conservative). As it has been said before; such similar societies tend to resist change.

Both communication and test anxiety can lead to fearing negative evaluation. Surprisingly, participants didn't show any feeling of embarrassment in communicating with native speakers. In my opinion, this is due to that native speakers are strangers to the participants, so communicating with them seems like a game or a piece of fun that gives them some pleasure. Those strangers are not part of their life or society so they do not feel any pressure or any kind of anxiety such as fear of negative evaluation.

To Sum up apprehension in communication and the other types of anxiety can de-motivate learners; and consequently cause insufficient attainment of language good proficiency.

\section{References}


Abu-Rabia, S. (2004). Teachers' Role, Learners' Gender Differences, and FL Anxiety Among Seventh- Grade Students Studying English as a FL. Educational Psychology, 24(5), 711-721. https://doi.org/10.1080/0144341042000263006

Aida, M. (1994). Examination of Horwitz, Horwitz, and Cope Construct of Foreign Language Anxiety: The case of students of Japanese. The Modern Language Journal, 78, 155-168. https://doi.org/10.1111/j.1540-4781.1994.tb02026.x

Alrabai, F. (2014). A Model of Foreign Language Anxiety in the Saudi EFL Context. English Language Teaching, 7(7), 82-101. https://doi.org/10.5539/elt.v7n7p82

Al-Saraj, T. M. (2014). Foreign Language Anxiety in Female Arabs Learning English: Case studies. Innovation in Language Learning and Teaching, 8(3), 257-278. http://dx.doi.org/10.1080/17501229.2013.837911

Awan, R., Azher, M., Nadeem, M., \& Naz, A. (2010). An Investigation of Foreign Language Classroom Anxiety and its Relationship with Students' Achievement. J. College Teach Learn, 7(11), 33-40. https://doi.org/10.19030/tlc.v7i11.249

Chan, D. Y. C., \& Wu, G. C. (2004). A Study of Foreign Language Anxiety of EFL Elementary School Students in Taipei County. Journal of National Taipei Teachers College, 17(2), 287-320.

Clement, R. (1980). Ethnicity, Contact and Communicative Competence in a Second Language. In H. Giles, W. P. Robinson, \& P. M. Smith (Eds.), Language: Social psychological perspectives (pp. 147-154). Oxford: Pergamon. Context. English Language Teaching, 7(7), 82-101.

Elkhafaifi, H. (2005). Listening Comprehension and Anxiety in the Arabic Language Classroom. The Modern Language Journal, 89, 206-220. http://dx.doi.org/10.1111/j.1540-4781.2005.00275.x

Ellis, R. (2008). The study of second language acquisition (2nd Ed.). Oxford: Oxford University Press.

Gkonou, C. (2012). A dairy Study on the Causes of English Language Classroom Anxiety. International Journal of English Studies

Horwitz, E. K., \& Young, D. J. (Eds.). (1991). Language anxiety From theory and Research to Classroom Implications. Englewood Cliffs, NJ: Prentice Hall

Horwitz, E. K. (1986). Preliminary Evidence for the Reliability and Validity of a Foreign Language Anxiety Scale. TESOL Quarterly, 20(3), 559-562. https://doi.org/10.2307/3586302

Horwitz, E. K., Horwitz, M. B., \& Cope, J. (1986). Foreign Language Classroom Anxiety. Modern Language Journal, 70(2), 125-32. https://doi.org/10.1111/j.1540-4781.1986.tb05256.x

MacIntyre, P. D., \& Gardner, R. C. (1989). Anxiety and Second Language Learning: Toward a Theoretical Clarification. Language Learning, 39, 251-275. https://doi.org/10.1111/j.1467-1770.1989.tb00423.x

MacIntyre, P. D. (1998). Language Anxiety: A review of the Research for Language Teachers. In D. J. Young (Ed.), Affect in Foreign Language and Second Language Learning (pp. 24-45). Boston: McGraw-Hill.

MacIntyre, P., \& Gardner, R. C. (1991) Investigating Language Class Anxiety Using the Focused Essay $\begin{array}{lllll}\text { Technique. The } & \text { Modern }\end{array}$ https://doi.org/10.1111/j.1540-4781.1991.tb05358.x

MacIntyre, P. D., \& Gardner R. C. (1991a). Anxiety and Second Language Learning: Towards a Theoretical Clarification. In: E. K. Horwitz, \& D. J. Young (Eds.), Language anxiety: From theory and research to classroom implications (pp. 41-54). Englewood Cliffs, New Jersey: Prentice Hall.

MacIntyre, P. D., \& Gardner, R. C. (1994b). The Subtle Effects of Language Anxiety on Cognitive Processing in the Second Language. Language Learning, 44(2), $283 \quad-305$. https://doi.org/10.1111/j.1467-1770.1994.tb01103.x

Matthews, G., Deary, I. J., \& Whiteman, M. C. (2003). Personality traits (2nd ed.). Cambridge: Cambridge University Press.perspective: Interview with Krashen, Omaggio Hadley, Terrell, and Rardin', Foreign Language Annals, 25, 157-172. https://doi.org/10.1017/CBO9780511812736

Salehi, M., \& Marefat, F. (2014). The Effect of Foreign Language Anxiety and Test Anxiety on Foreign Language Test Performance. Theory and Practice in Language Studies, 4(5), 931-940. https://doi.org/10.4304/tpls.4.5.931-940

Trang, T. T. T. (2012). A review of Horwitz, Horwitz and Cope's Theory of Foreign Language Anxiety and the Challenges to the Theory. English Language Teaching , 5(1), 69-75. 
Young, D. J. (1992). Language Anxiety from the Foreign Language Specialist's Perspective: Interviews with Krashen, Omaggio Hadley, Terrell, and Rardin. Foreign Language Annals, 25, 157-172. https://doi.org/10.1111/j.1944-9720.1992.tb00524.x

Zhang, L. J. (2001). Exploring Variability in Language Anxiety: Two groups of PRC Students Learning ESL in Singapore. RELC Journal, 32(73), 73-91. https://doi.org/10.1177/003368820103200105

\section{Copyrights}

Copyright for this article is retained by the author(s), with first publication rights granted to the journal.

This is an open-access article distributed under the terms and conditions of the Creative Commons Attribution license (http://creativecommons.org/licenses/by/4.0/). 